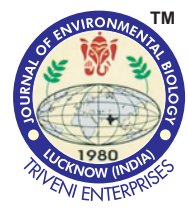

\title{
Distribution and indicator species of zooplankton in the East Sea, Yellow Sea and Northern East China Sea in winter
}

\section{Authors Info \\ J.Y. Lee', W. Park² ${ }^{2 *}$ S.Y. Moon ${ }^{3}$ and H.K.Cha ${ }^{4}$ \\ ${ }^{1}$ Northwest Pacific Action Plan Marine Environmental Emergency Preparedness and Response Regional Activity Center (NOWPAP MERRAC), Korea Research Institute of Ships \& Ocean Engineering (KRISO), Daejeon, 34103, Korea ${ }^{2}$ Department of Marine Biology, Pukyong National University, Busan, 48513, Korea \\ ${ }^{3}$ Fisheries Resource Survey Center, National Institute of Fisheries Science, Tongyoung, 53063, Korea \\ ${ }^{4}$ National Institute of Fisheries Science, Busan, 46083, Korea \\ *Corresponding Author Email : wpark@pknu.ac.kr}

\section{Edited by}

Professor Chung II Lee

\section{Reviewed by} Professor Hyun Jei Park Dr. Jung Nyun Kim

\section{Abstract}

Aim: Zooplankton are distributed by hydrographic factors such as temperature and salinity. The research aims to investigate the distribution patterns of zooplankton and indicator species of water bodies, and to understand the relationship between zooplankton distribution and water bodies in Korean waters in winter.

Methodology: Zooplankton, samples were collected and temperatures and salinities were recorded at 130 stations around Korean peninsula in the Yellow Sea and the northern East China Sea (ECS), using a Bongo net and CTD in winter, 2016. Research areas using K-mean clustering based on temperatures and salinities were divided into six water bodies:the North Korea Cold Current (NKCC), the East Korea Warm Current (EKWC), the Jeju Warm Current (JWC), the Yellow Sea Warm Current (YSWC), the Yellow Sea (Y1), and mixed water. The indicator indices for water bodies were calculated using INSPAN (Indicator Species Analysis).

Results: NKCC, YSWC and Y1 were represented by high proportions of cold water species of 81,44 and 41 species, respectively, while EKWC and JWC were relatively dominated by warm water species of 99 and 102 species. The water bodies of Yellow Sea and the northern ECS were greatly similar, but the East/Japan Sea was significantly distinguished. With the Indicator value and distribution, indicator species for water bodies were identified: Scolecithricella minorin the NKCC, Candacia bipinnata, Clausocalanus furcatus, and Pleuromamma gracilisin the EKWC, Scolecithricella longispinosa and Euchaeta plana in the JWC, Centropages abdominalis in the $Y 1$.

Interpretation: Distributions of zooplanktons and the similarity of community structures were determined by the interaction of water bodies. Zooplankton species can be used as indicator of water bodies because of their dependence on ocean currents.

Key words: East Sea, Indicator species analysis, Zooplankton

\section{The research aimed to investigate the distribution patterns of zooplankton and indicator species of water bodies, and to understand the relationship between the zooplankton distribution and water bodies in Korean waters in winter.}

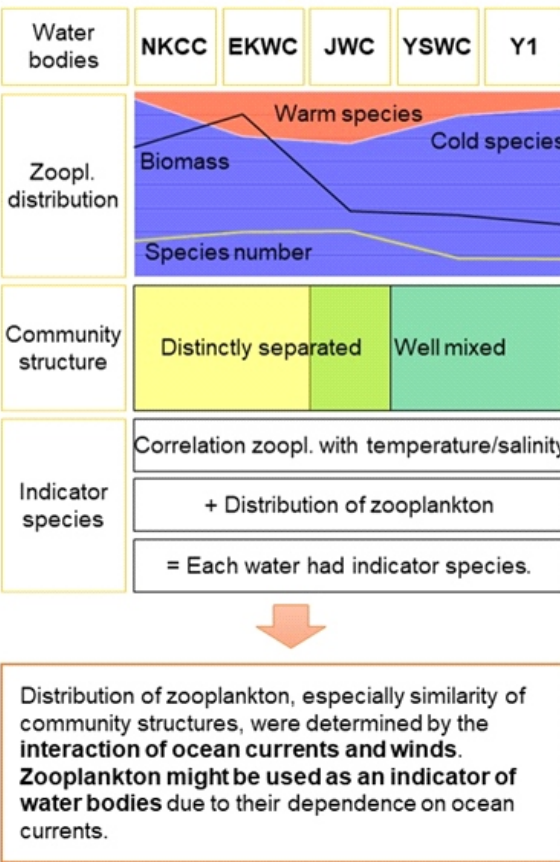

How to cite : Lee, J.Y., W. Park, S.Y. Moon and H.K.Cha: Distribution and indicator species of zooplankton in the East Sea, Yellow Sea and Northern East China Sea in winter. J. Environ. Biol., 40, 871-883 (2019). DOI : http://doi.org/10.22438/jeb/40/5(SI)/SI-07 


\section{Introduction}

The Korean peninsula is enclosed by the East Sea, the East China Sea and the Yellow Sea, which are characterized by different physical and biological features (Rebstock and Kang, 2003). In the East Sea, the East Korean Warm Current (EKWC) and North Korean Cold Current (NKCC) create a well-defined sub-polar front (Yoon, 1982; Isoda et al., 1992; Kim et al., 1998). The EKWC which is a branch of Kuroshio Warm Current (KWC) supplies heat and salts to Korean waters by flowing northward (Yasui et al., 1967), and the NKCC which is a branch of Oyashio Cold Current provides high nutrients.

In the Southern Sea of Korea, the northward flowing warm water flows into the Yellow Sea and the Korean Strait after passing through the northern ECS. To the east, the northern ECS boards on Kyushu, and to the west, it boards the mainland of China (Lee, 1992). The hydrography of northern ECS is characterized by Taiwan Warm Current (TaWC) originated in the KWC, Jeju Warm Current (JWC) as a branch of TaWC (Nitani, 1972; Fang et al., 1991; Teague et al., 2003) and coastal water such as the Yangtze Diluted Water (YDW) (Lie et al., 2002; Beardsley et al., 1985). Also, the Yellow Sea Cold Bottom Water (YSCBW) and the Yellow Sea Warm Current (YSWC) are formed in the ECS (Nitani, 1972). In particular, a strong thermohaline front forms across the south of Jeju Island and separates the coastal water from the JWC.

The Yellow Sea consists of YSCBW, YSWC, the Korea Coastal Current and YDW, overlying shallow continental shelf with average depth of approximate 44 m (Uda, 1934; Lee, 1968; Lie, 1984). Each water mass has its own distinct characteristics and interact ion with each other (Teague et al., 2003).

Functioning of marine ecosystem is strongly affected by zooplankton community (Dur et al., 2007). Also, the structuring of zooplankton communities is dependent on large scale physical processes such as transport of water masses by current in various ecosystems (Hwang and Wong, 2005; Hwang et al., 2006; Tseng et al., 2008). In the East/Japan Sea, variety of zooplankton species appear by sub-polar front not only warm water species, but cold water species (Park et al., 1998). The Northern East China Sea (ECS), the gate of warm water moving northward, comprises high diversity with a tropical and subtropical species (Jang et al., 2012), while Yellow Sea characterizes low diversity, but high biomass.

Among zooplankton, copepods are major food of fish larvae and express a most dominant zooplankton group in marine ecosystem (Lan et al., 2004). In the East/Japan Sea and northern ECS, copepods are dominated, while Sagittidae spp. juveniles are abundant in the Yellow Sea (Rebstock et al., 2003). Some copepod species indicate a certain water mass (Brodsky, 1950; Hwang et al., 2006). Centropages abdominalis and Metridia pacifica are cold water species (Brodsky, 1950), while Clausocalanus arcuicornis, C. furcatus, Scolecithrix danae and Paracalanus aculeatus belong to warm water species (Hsieh et al., 2004; Hwang et al., 2006).

Zooplankton communities vary with varying water masses and few comparisons of biological features of three seas have already been published. Keeping in view of the above, this study aimed to investigate the community structure and indicator species of zooplankton around the Korea peninsula.

\section{Materials and Methods}

Sampling : Zooplanktons were collected from 130 stations in Korean waters during winter season of 2016. (Fig. 1). Zooplanktons were collected using a Bongo net (the mouth diameter of $80 \mathrm{~cm}$ and the mesh size of $333 \mu \mathrm{m}$ ). The net was towed double-obliquely hauling up to near the bottom to the surface with a flow meter. If the depth of water $>200 \mathrm{~m}$, the net was towed to maximum $100 \mathrm{~m}$. Zooplanktons were preserved in $70 \%$ ethyl alcohol. Vertical temperature and salinity profiles were measured with a CTD (SBE 9 plus) at $1 \mathrm{~m}$ depth interval at the sampling stations.

In laboratory, samples were scanned before analysis under a stereomicroscope. Approximate by 300-500 zooplankton organisms were splitted for analysis using a Motoda splitter and then enumerated in a Bogorov counting tray. Copepods were identified to species level and other zooplanktons were identified to the lowest taxonomical level if possible.

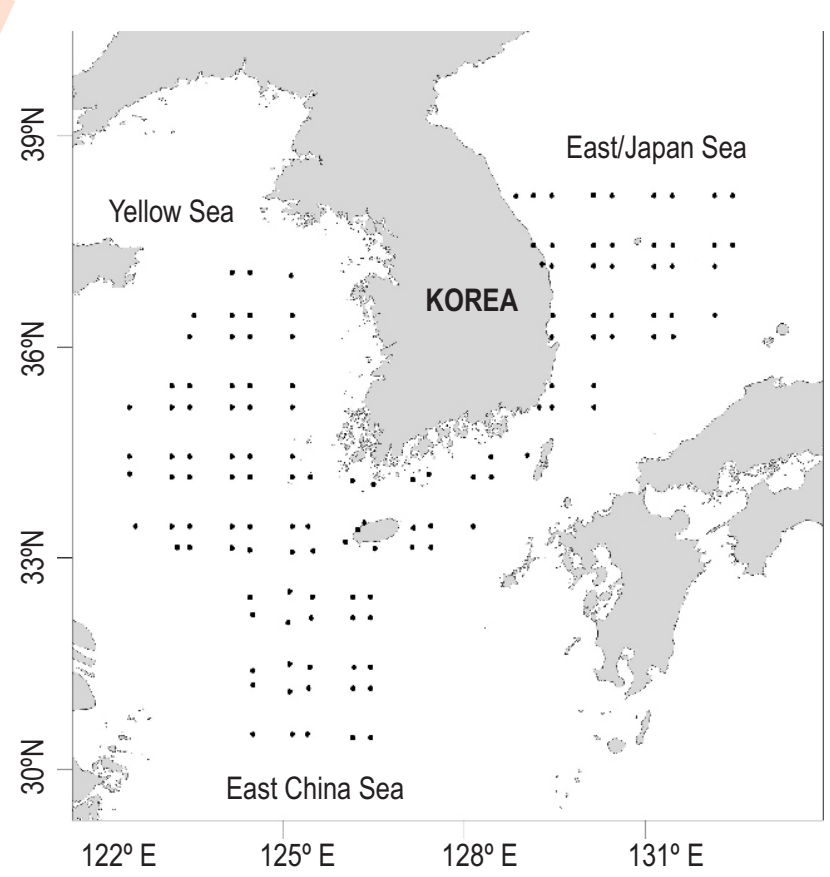

Fig. 1 : Map of sampling stations in Korean waters. Each symbol indicates sampling areas in Korean waters in winter 2016. 
Data analysis : Species diversity ( $\left.\mathrm{H}^{\prime}\right)$ was calculated by Shannon and Wiever (1963). Cluster analysis using Bray-Curtis similarity matrix was used to analyze the similarity of zooplankton communities by stations at $60 \%$ similarity level. To find a difference between communities, One-way ANOSIM (analysis of similarity) was conducted with PRIMER (version 6.1.6) (Clarke et al., 2001). Spearman rank correlation coefficient was used to compare the sea surface water temperature, sea surface water salinity and the densities of dominant and indicator species in Korean waters using SPSS $12.0 \mathrm{~K}$.

Indicator species analysis : Korean waters were divided by sea surface temperature and salinity using K-means clustering. Vertical profiles of sea surface temperature and salinity were investigated with ODV (Ocean Data View 4). Prior to investigate species representing water masses, indicator species value was calculated by Dufrene and Legendre (1997) and over $60 \%$ of indicator species value was selected as indicator species. The Indicator value (Ind-Val) of individual species was calculated as by the following equation:

$$
\text { Ind-Val }=\mathrm{RA}_{k j} \times \mathrm{RF}_{k j} \times 100
$$

$R A k j=\frac{\text { Mean number of individuals of species } j \text { across sites of group } k}{\text { Sum of the mean numbers of individuals of species } j \text { overall group }}$

$$
\mathrm{RF} k j=\frac{\text { The number of sites in cluster } k}{\text { Total number of sites in that cluster } k}
$$

Where, RA is the relative abundance of species in group $k, R F$ is the relative frequency (presence/absence) of species $j$ in group $k$. Monte-Carlo method was used to test the significance of Ind-Val by randomly permuting the data and recalculating Ind-Val. The result was deemed significant at $<0.05$ with PC-ORD.

\section{Results and Discussion}

Oceanographic characteristics: Sea surface temperature ranged between $4.5-16.5^{\circ} \mathrm{C}$, it was highest in the eastern part of ECS and lowest in the northern Yellow Sea. Surface salinity ranged between31.89-34.71psu, it was highest at the eastern Jeju Island and lowest in the western sea of ECS (Fig. 2).

Korean waters were divided into six water bodies: (A), (B), (C), (D), (E), and (F), consisting of 15, 36, 30, 20, 19 and 10 stations, respectively. Group (C) was characterized by the highest sea surface temperature and salinity whereas Group $(E)$ and $(F)$ was characterized by lowest sea surface temperature and salinity (Fig. 3; Table 1).

In the East Sea, warm current and cold current clearly varied within $37.25^{\circ} \mathrm{N}$. Also, cold current appeared at water depth deeper than $50 \mathrm{~m}$ with lowest temperature of $1.26^{\circ} \mathrm{C}$. Warm water had a highest temperature of $12.63^{\circ} \mathrm{C}$. In the Yellow Sea, water masses were relatively homogenous. In the northern ECS, warm hypersaline water and cold hyposaline water were strongly separated within $125.5^{\circ} \mathrm{E}$. Warm hypersaline water had a highest temperature and salinity of $16.41^{\circ} \mathrm{C}$ and $34.66 \mathrm{psu}$, while cold hyposaline water had a lowest temperature and salinity of $8.95^{\circ} \mathrm{C}$ and 32.42 psu (Fig. 4).

Water bodies consisted of 6 currents: Group (A) as NKCC; group (B) as EKWC; group (C) as JWC; group (E) as YSWC and group (F) as original water bodies of Yellow Sea and
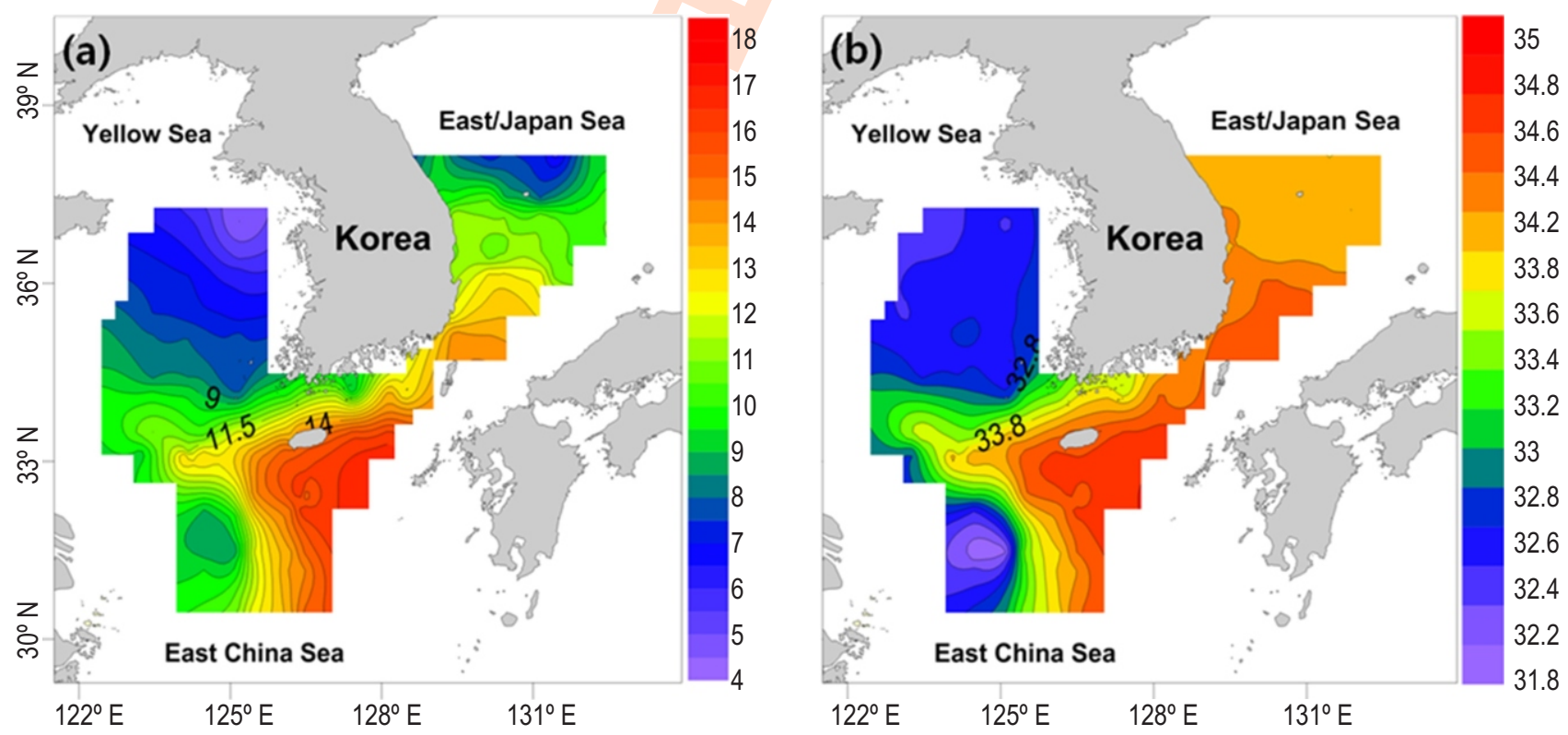

Fig. 2 : Horizontal distribution of temperature and salinity at $10 \mathrm{~m}$ depth in winter 2016. (a) Temperature, (b) Salinity. 


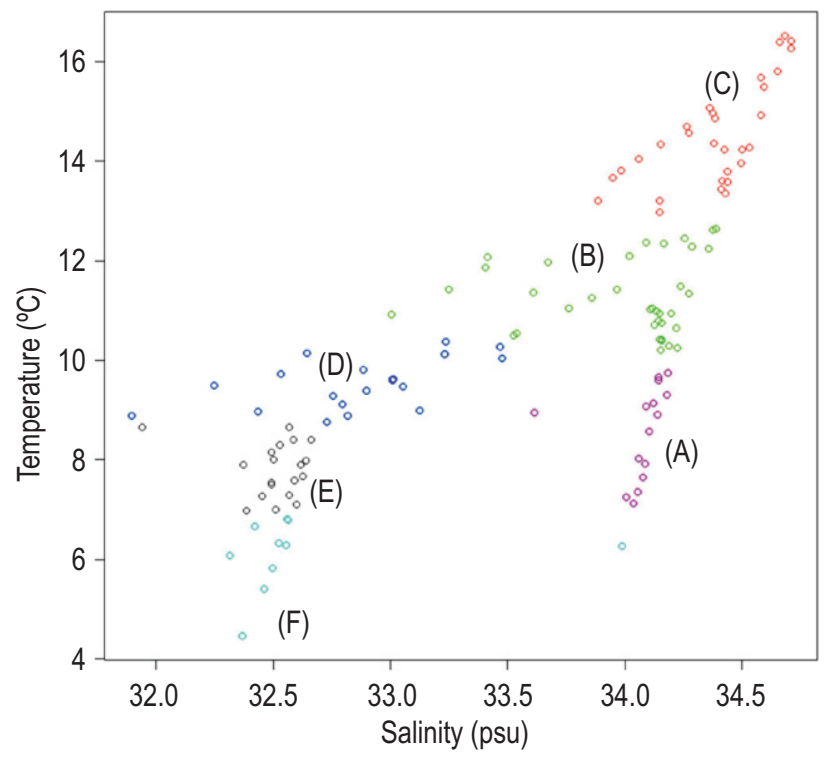

Fig. 3: Temperature-Salinity diagram of clustering groups in winter 2016.
Y1. In addition, complex currents distributed around the JWC were defined as mixed water (Fig. 5).

Distribution of water bodies in Korean waters: The East Sea is deepest with a wide and varied vertical range of temperature due to sub-polar front made of EKWC and NKCC. EKWC transported Tsushima Warm Current (TsWC) with high salinity and temperature along the eastern coast. Under EKWC, NKCC within $1-4^{\circ} \mathrm{C}$ prevailed from 50 to $100 \mathrm{~m}$ depth along the coastal water of Gangwon Province in February (Cho and Kim, 1994; Choi et al., 2012). In the East/Japan Sea, the EKWC and NKCC creating sub-polar front is located at 38-39úN (Yoon, 1982; Isoda et al., 1992; Kim et al., 1998). In the present study, sub-polar front was formed more southward than where was reported at 37 ÚN due to enhanced NKCC in winter (Park et al., 2007). Also, sea surface layer prevailed due to warm water over $10^{\circ} \mathrm{C}$, while sea bottom was occupied by cold water below $4^{\circ} \mathrm{C}$ in the sub-polar front region.

(a)
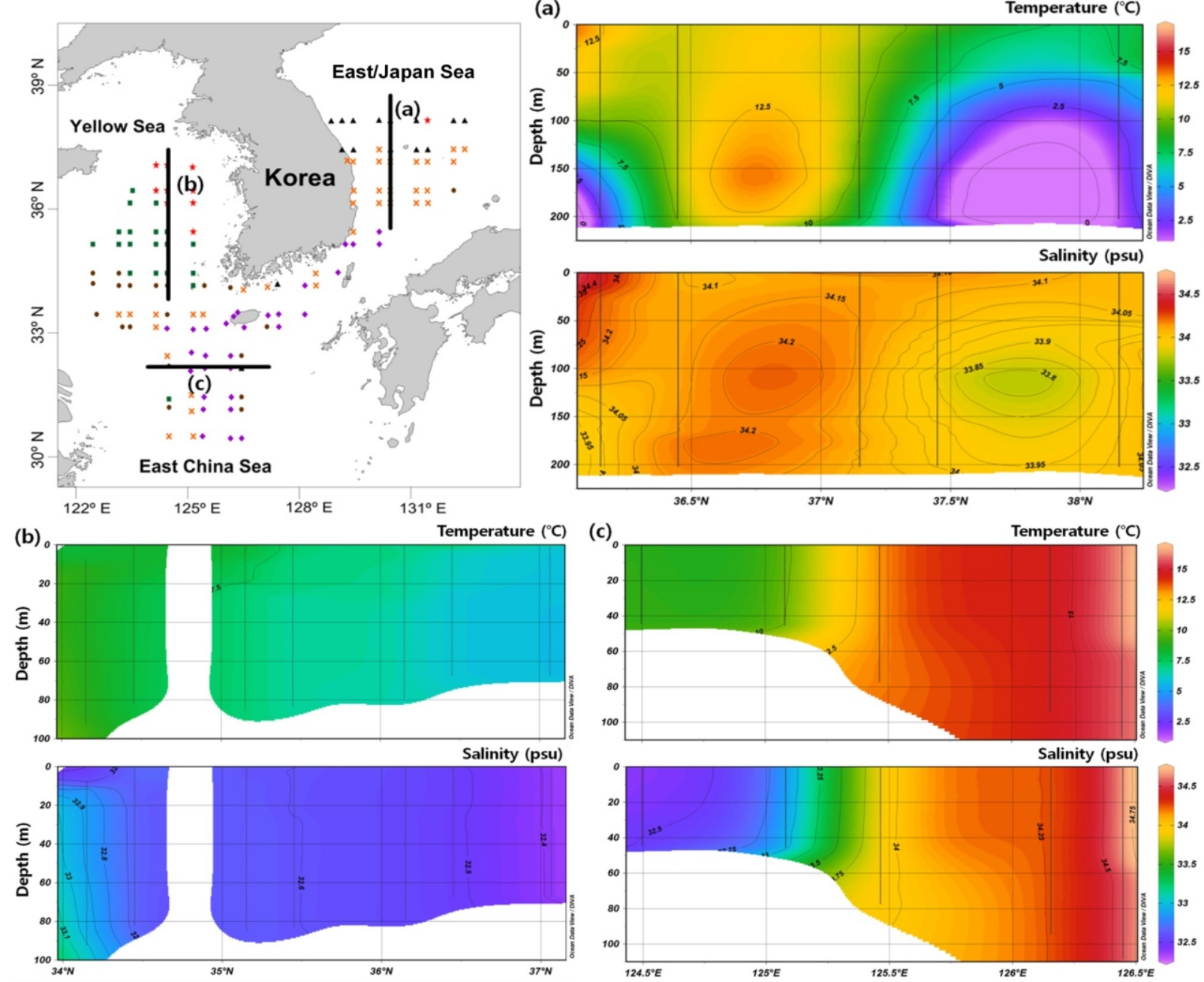

Fig. 4 : Cross sections of temperature and salinity along three solid lines. (a) East Sea, (b) Yellow Sea, (c) Northern East China Sea. 
Table 1: Average temperature and salinity of each clustering groups in winter 2016

\begin{tabular}{lll}
\hline Clustering & Average temperature (!) & Average salinity (psu) \\
\hline (A) & 8.55 & 34.07 \\
(B) & 11.28 & 34 \\
(C) & 14.53 & 34.39 \\
(D) & 9.53 & 32.86 \\
(E) & 7.8 & 32.51 \\
(F) & 6.09 & 32.62 \\
\hline
\end{tabular}

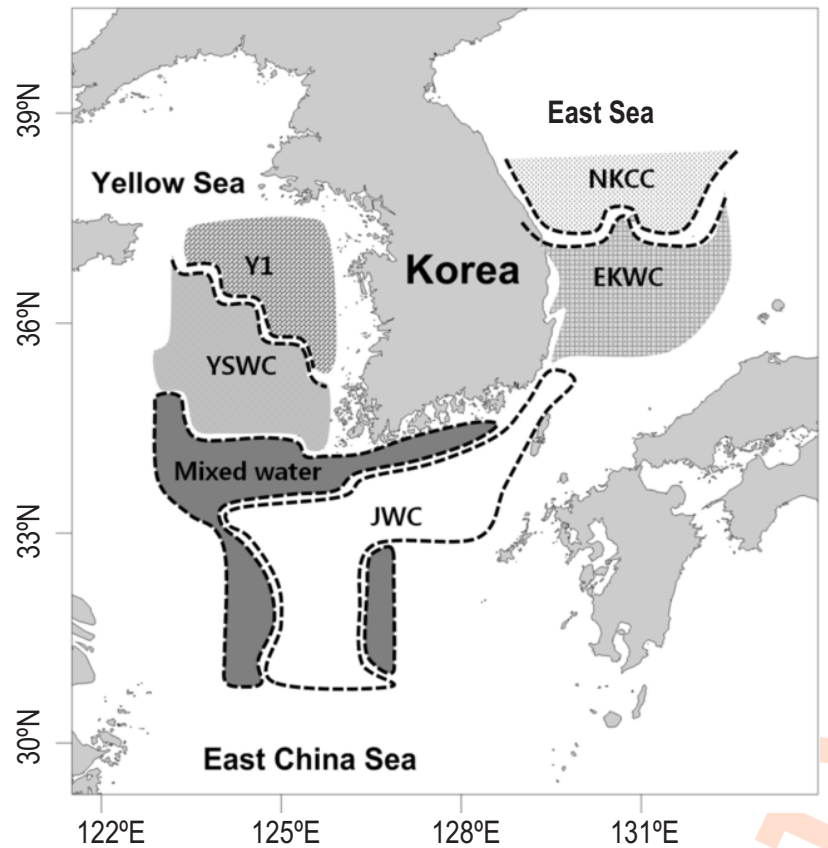

Fig. 5 : Distributions of the water masses. (A): NKCC, (B): EKWC, (C): JWC, (D): Mixed water, (E):YSWC, (F):Y1.

Northern ECS is a route of northward moving warm water. Warm water such as JWC makes a thermohaline front with YDW (Lie et al., 2001). JWC flows into the Jeju Strait after turning clockwise around Jeju Island, with over $10^{\circ} \mathrm{C}, 33.5-34.0 \mathrm{psu}$ (Lie et al.,1999; Lie et al., 2000, 2001). Upon investigation of tracking Jeju currents, the JWC was distinguished from Kuroshio branch water located in the east coast of Jeju Island, and partially affects the TsWC through Korea Strait (Lie et al., 2000). Also, Yangtze river runoff accounts for more than $80 \%$ of freshwater, released a range of $9,900-10,200 \mathrm{~m}^{3} / \mathrm{s}$ in northern ECS (Riedlinger et al., 1995). Similar to previous studies, northern ECS produced thermohaline front with various water bodies, such as JWC and mixed water influenced by coastal water.

During winter, the Yellow Sea is affected by northwest winds, southward China coastal water and Korean coastal water (Hsueh, 1988; Riedlinger et al., 2000; Naimie et al., 2001). The YSWC enhancing during winter flows northward to the Yellow Sea with heat and saline (Hwang et al., 2014). In our research, YSWC was characterized by low salinity and temperature, which werenot coincided with previous studies. However, mean sea surface water temperature and salinity in the KCC in the Yellow Sea were $6^{\circ} \mathrm{C}$ and32.5, which was similar to previous study (Koh et al., 2014).

Species composition and abundance : A total of 199 species of zooplankton belonging to ten phyla were identified. Of these, 170 species were arthropods and 126 species were copepods. The species number was highest (102) in JWC followed by 99 species in EKWC, 81 species in NKCC, 44 species in YSWC, and 41 species in $Y 1$.

Zooplankton densities ranged between 7.6-926.5 inds.m ${ }^{3}$. The mean density of zooplankton was highest $\left(351.4\right.$ inds. $\left.\mathrm{m}^{-3}\right)$ in EKWC followed by NKCC, JWC, YSWC and Y1 (115.1 inds. $\mathrm{m}^{-3}$ ). Species diversity indices ranged from 0.91 to 3.12. Average of the index was highest in EKWC (2.67), followed by NKCC, JWC, YSWC and Y1 (2.01). Diversity was not proportional to the biomass (Fig. 6).

The most dominant species in NKCC were Pseudocalanus newmani, Metridia pacifica and Oithona atlantica, and cold water copepods comprising 96\% were dominated. Warm water copepods were relatively high in JWC (28\%) and EKWC (24\%). In EKWC, dominant species were Pseudocalanus minutus, Oithona plumifera and Metridia pacifica. In JWC and Y1, dominant species wasCalanus sinicus. In YSWC, dominant species were Calanus sinicus, Oithona atlantica and Paracalanus parvus s.I. (Table 2; Fig. 7), respectively.

In the East Sea, cold water species such asM. pacifica, $P$. newmani, O. atlantica and $P$. parvus s.I. charged $46.2 \%$.Warm water copepods of $M$. tenuicornis, Clausocalanus pergens, Ditrichocorycaeus affinis and C. arcuicornis occupied $14.4 \%$ in winter (Chiba et al., 2003). In this study, cold water copepods such as $P$. newmani, M. pacifica and $O$. atlantica were dominated, coinciding with previous studiesof Chiba et al. (2003) and Kang et al. (2007). The prevailing cold water species may result from NKCC due to sampling layer deeper than $100 \mathrm{~m}$ depth.

C. sinicus is dominated in the ECS (Chen et al., 1992) and $P$. parvus s.l. is abundant in off China coastal water (Chen et al., 1974). Also, P. aculeatus, C. sinicus, Ostracoda and 

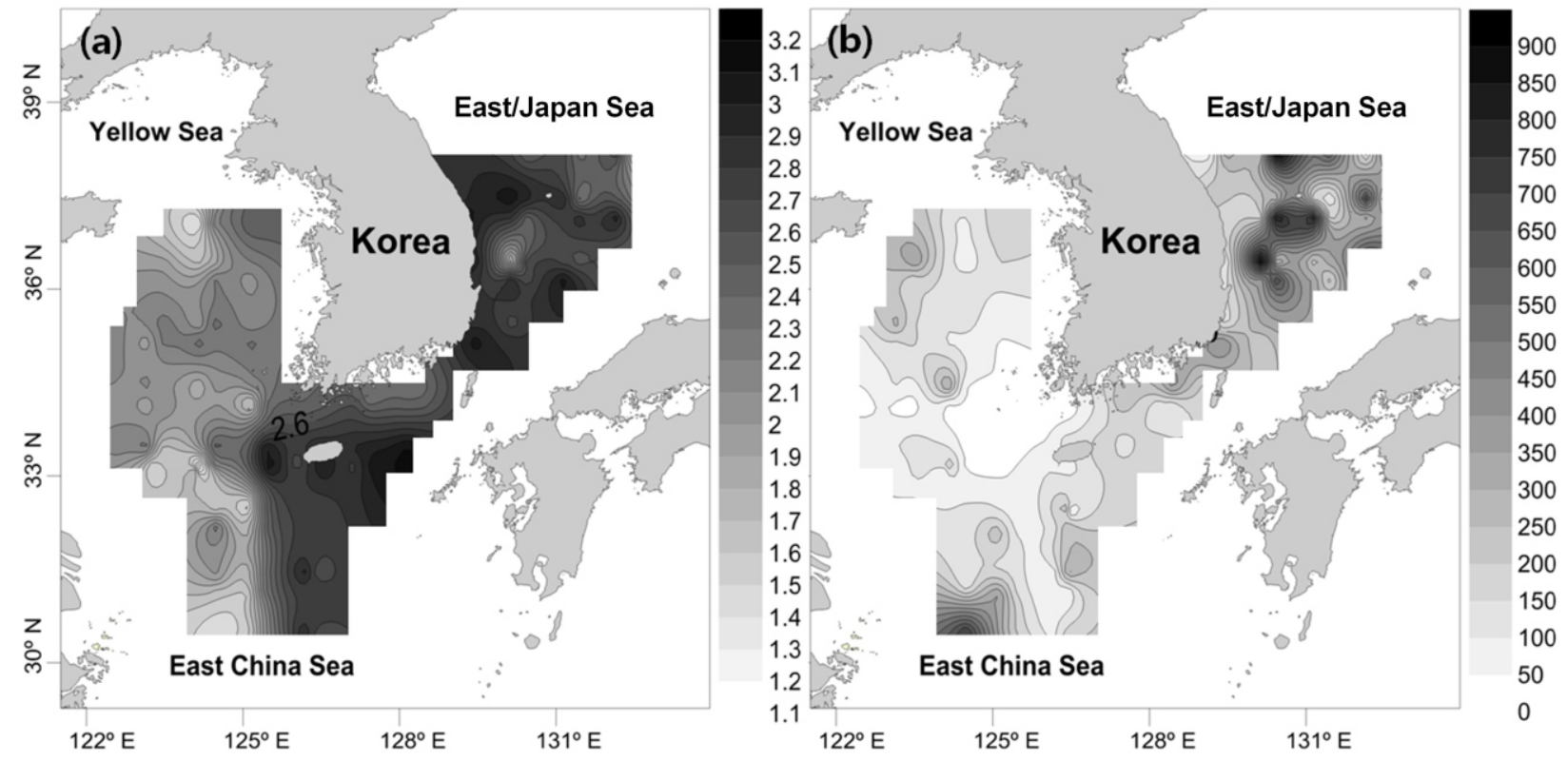

Fig. 6 : Horizontal distribution of zooplankton density (inds. $\mathrm{m}^{-3}$ ) and species diversity indices in Korean waters in winter 2016. (a) Density, (b) Diversity indices.

Table 2 : Mean abundance and composition of dominant mesozooplankton by water masses in winter 2016

\begin{tabular}{|c|c|c|c|}
\hline Current & Species & Mean abundance (inds.ms) & Composition (\%) \\
\hline \multirow[t]{5}{*}{ NKCC } & Pseudocalanus newmani & 54.41 & 19.84 \\
\hline & Metridia pacifica & 33.73 & 12.3 \\
\hline & Metridia sp. copepodite & 23.87 & 8.7 \\
\hline & Oithona atlantica & 19.66 & 7.17 \\
\hline & Neocalanus spp. copepodite & 15.24 & 5.56 \\
\hline \multirow[t]{5}{*}{ EKWC } & Pseudocalanus minutus & 70.28 & 19.30 \\
\hline & Metridia sp. copepodite & 26.47 & 7.27 \\
\hline & Oithona plumifera & 23.05 & 6.33 \\
\hline & Metridia pacifica & 22.71 & 6.24 \\
\hline & Calanoida spp.copepodite & 16.65 & 4.57 \\
\hline \multirow[t]{5}{*}{ JWC } & Calanus sp. copepodite & 33.16 & 28.57 \\
\hline & Calanus sinicus & 9.57 & 8.25 \\
\hline & Euchaetidae spp. copepodite & 8.80 & 7.59 \\
\hline & Calanoida spp.copepodite & 7.76 & 6.69 \\
\hline & Sagittidae spp. juvenile & 7.28 & 6.27 \\
\hline \multirow[t]{5}{*}{ YSWC } & Calanus sp. copepodite & 21.87 & 20.76 \\
\hline & Calanus sinicus & 18.83 & 17.88 \\
\hline & Oithona atlantica & 18.23 & 17.31 \\
\hline & Sagittidae spp. juvenile & 16.40 & 15.57 \\
\hline & Paracalanus parvuss.l. & 4.85 & 4.61 \\
\hline \multirow[t]{5}{*}{ Y1 } & Sagittidae spp. juvenile & 25.49 & 22.11 \\
\hline & Calanus sp. copepodite & 19.52 & 16.93 \\
\hline & Calanus sinicus & 17.96 & 15.58 \\
\hline & Calanidae spp. copepodite & 6.19 & 5.37 \\
\hline & Calanoida spp. copepodite & 5.73 & 4.97 \\
\hline
\end{tabular}


Cold water copepods

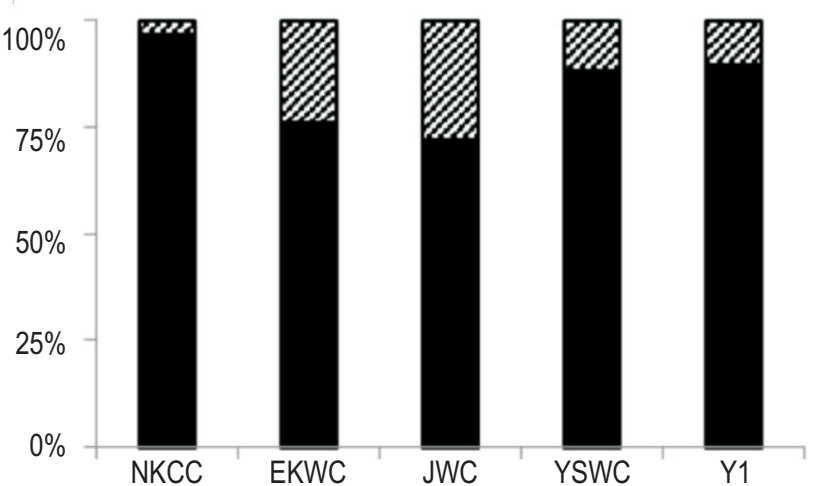

Fig. 7 : Compositions of warm and cold water species of 30 dominant copepods by water masses in winter 2016 .

Siphonophora were dominated in winter in northern ECS (Park et al., 2000). $P$. aculeatus is reported as a warm indicator species of Kuroshio branch current (Hsieh et al., 2004). Likewise, effect of JWC made relatively high density of $P$. aculeatus with a high proportion of warm water copepods, and also JWC was dominated by $C$. sinicus and chaetognath juvenile.

Acartia bifilosa, A. omorii, C. sinicus, D. affinis, Eurytemora pacifica, Pavocalanus crassirostris and $P$. indicus were dominated in the Yellow Sea (Kim et al., 1991). In particular,
C. sinucus, P. parvus s.l., O. atlantica, D. affinis and O. similis were abundant during winter (Lim et al.,2009). In this study, C. sinicus was found to be the dominant species in YSWC and Y1. In YSWC, high population of $P$. parvus s.I. was due to the effect of warm water coming from northern ECS.

Zooplankton communities : nMDS analysis indicated that zooplankton communitiesin NKCC, EKWC and JWC were distinctly separated, and several stations of JWC were included in YSWC, Y1, and mixed water (Fig. 8). As a result of SIMPER analysis, NKCC and JWC showed highest dissimilarity, while YSWC and Y1 showed the lowest dissimilarity. In pairwise tests, combination among YSWC, Y1 and mixed water were not significantly different. The NKCC did not differ significantly from the EKWC and the JWC was not significantly distinguished from mixed water. Combinations for others were significantly different (Table 3).

Zooplankton community structure : The East/Japan Sea, northern ECS and the Yellow Sea are well associated. The northern ECS and the Yellow Sea interact with YSWC and coastal water, varying with seasons (Ichikawa et al., 2002; Lee et al.,2007; Chen 2009). Zooplankton assemblages and water mass distributions are associated (Chen et al.,2015). Zooplankton communities between the Yellow Sea and northern ECS showed $60 \%$ dissimilarity in fall (Chen et al.,2015), while those between two seas were similar in study. This difference may be influenced

MDS results of zooplankton

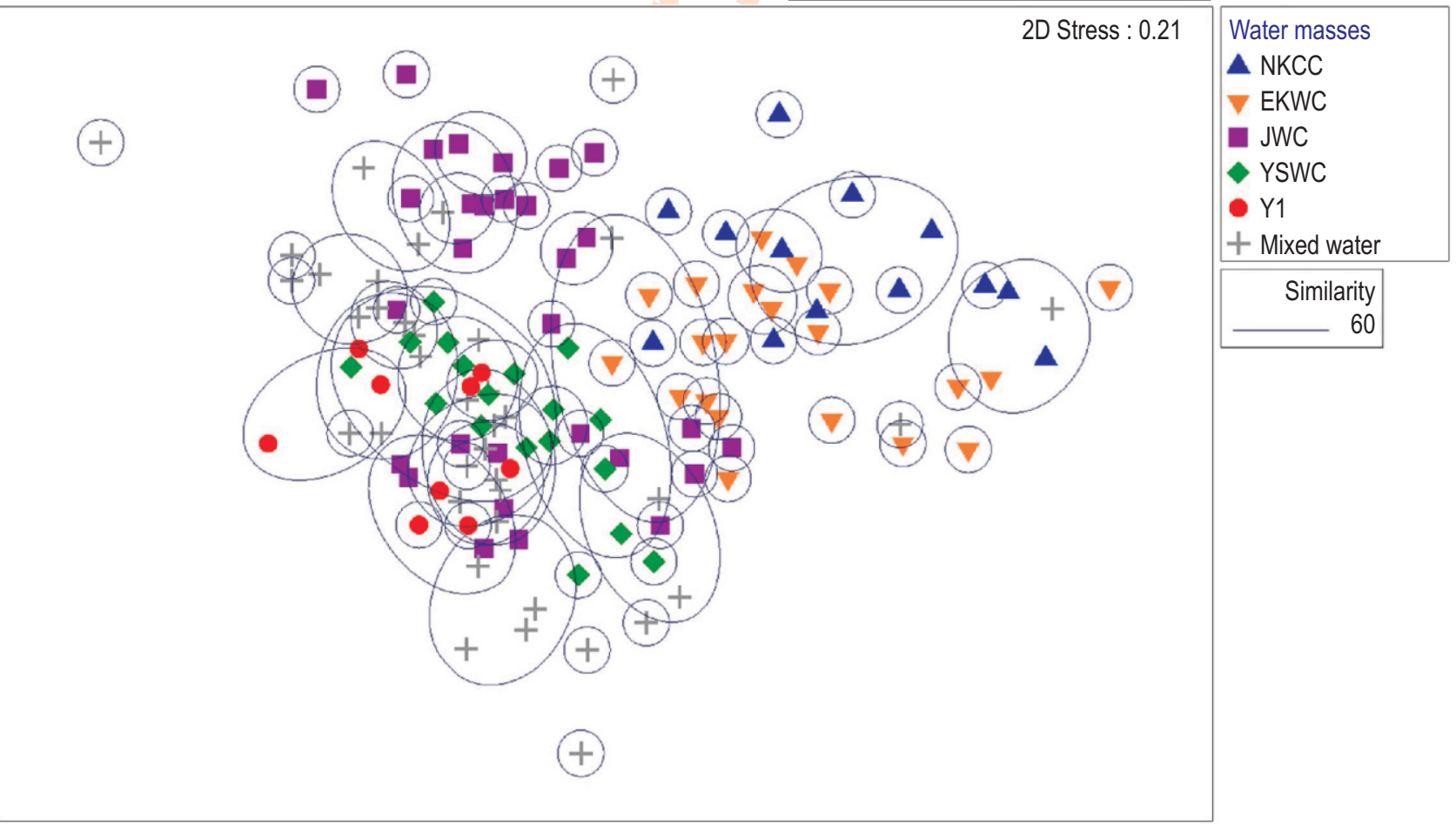

Fig. 8 : Result of MDS grouping in winter.

* Journal of Environmental Biology, Special Issue, September 2019 * 
Table 3 : Results of SIMPER and ANOSIM pair-wise tests for difference on mesozooplankton community between groups in winter 2016

\begin{tabular}{|c|c|c|c|c|}
\hline \multirow[t]{2}{*}{ Groups } & \multirow[t]{2}{*}{ versus groups } & \multirow{2}{*}{$\frac{\text { SIMPER }}{\text { Average dissimilarity }}$} & \multicolumn{2}{|c|}{ Pairwise Tests } \\
\hline & & & R statistics & $p$-level \\
\hline \multirow[t]{5}{*}{ NKCC } & EKWC & 68.66 & 0.115 & 3.6 \\
\hline & JWC & 87.02 & 0.829 & 0.1 \\
\hline & YSWC & 83.81 & 0.89 & 0.1 \\
\hline & Y1 & 86.44 & 0.894 & 0.1 \\
\hline & Mixed water & 86.69 & 0.559 & 0.1 \\
\hline \multirow[t]{4}{*}{ EKWC } & JWC & 81.8 & 0.576 & 0.1 \\
\hline & YSWC & 80.34 & 0.68 & 0.1 \\
\hline & Y1 & 83.53 & 0.709 & 0.1 \\
\hline & Mixed water & 83.9 & 0.453 & 0.1 \\
\hline \multirow[t]{3}{*}{ JWC } & YSWC & 75.5 & 0.385 & 0.1 \\
\hline & Y1 & 76.95 & 0.364 & 0.1 \\
\hline & Mixed water & 74.95 & 0.106 & 0.2 \\
\hline \multirow[t]{2}{*}{ YSWC } & Y1 & 58.44 & 0.105 & 9.6 \\
\hline & Mixed water & 71.45 & 0.031 & 29.4 \\
\hline Y1 & Mixed water & 72.28 & -0.018 & 54.5 \\
\hline
\end{tabular}

Table 4 : Results of Spearman rank correlation coefficient between dominant species and temperature and salinity in winter.'- means $p$-value, $>0.05$

\begin{tabular}{|c|c|c|c|c|c|}
\hline \multirow[t]{2}{*}{ Current } & \multirow[t]{2}{*}{ Species } & \multicolumn{2}{|c|}{ Temperature } & \multicolumn{2}{|c|}{ Salinity } \\
\hline & & $r$ & $p$ & $r$ & $\mathrm{p}$ \\
\hline \multirow[t]{5}{*}{ NKCC } & Pseudocalanus newmani & -0.116 & - & 0.306 & $<0.001$ \\
\hline & Metridia pacifica & 0.089 & - & 0.439 & $<0.001$ \\
\hline & Metridiasp. copepodite & -0.120 & - & 0.297 & $<0.001$ \\
\hline & Oithona atlantica & -0.253 & $<0.01$ & 0.086 & - \\
\hline & Neocalanus spp. copepodite & -0.105 & - & 0.316 & $<0.001$ \\
\hline \multirow[t]{5}{*}{ EKWC } & Pseudocalanus minutus & 0.105 & - & 0.442 & $<0.001$ \\
\hline & Metridia sp. copepodite & -0.120 & - & 0.297 & $<0.001$ \\
\hline & Oithona plumifera & -0.119 & - & 0.017 & - \\
\hline & Metridia pacifica & 0.089 & - & 0.439 & $<0.001$ \\
\hline & Calanoida spp.copepodite & -0.304 & $<0.001$ & -0.234 & $<0.01$ \\
\hline \multirow[t]{5}{*}{ JWC } & Calanus sp. copepodite & 0.057 & - & -0.244 & $<0.01$ \\
\hline & Calanus sinicus & -0.336 & $<0.001$ & -0.407 & $<0.001$ \\
\hline & Euchaetidae spp. copepodite & 0.793 & $<0.001$ & 0.760 & $<0.001$ \\
\hline & Calanoida spp.copepodite & -0.304 & $<0.001$ & -0.234 & $<0.01$ \\
\hline & Sagittidae spp.juvenile & -0.296 & $<0.001$ & -0.466 & $<0.001$ \\
\hline \multirow[t]{5}{*}{ YSWC } & Calanus sp. copepodite & 0.057 & - & -0.244 & $<0.01$ \\
\hline & Calanus sinicus & -0.336 & $<0.001$ & -0.407 & $<0.001$ \\
\hline & Oithona atlantica & -0.253 & $<0.01$ & 0.086 & - \\
\hline & Sagittidae spp. juvenile & -0.296 & $<0.001$ & -0.466 & $<0.001$ \\
\hline & Paracalanus parvuss.l. & 0.220 & $<0.05$ & 0.142 & - \\
\hline \multirow[t]{5}{*}{ Y1 } & Sagittidae spp. juvenile & -0.296 & $<0.001$ & -0.466 & $<0.001$ \\
\hline & Calanus sp. copepodite & 0.057 & - & -0.244 & $<0.01$ \\
\hline & Calanus sinicus & -0.336 & $<0.001$ & -0.407 & $<0.001$ \\
\hline & Calanidae spp. copepodite & -0.097 & - & 0.013 & - \\
\hline & Calanoida spp.copepodite & -0.304 & $<0.001$ & -0.234 & $<0.01$ \\
\hline
\end{tabular}

by YSWC and the Korea coastal current, prevailing during winters (Kondo, 1985). YSWC plays an important role in transporting heat and salt to the Yellow Sea (Ichikawa et al.,2002; Lie et al., 2000), and KCC flows southward along west Korea due to strong north wind in winter (Koh et al.,2014).
Zooplankton communities of the East Sea separated from other seas are determined by the path of currents. EKWC and JWC originate from KWC (Rebstock et al., 2003). However, two water bodies showed different physical properties (Lie et al., 1994). KWC makes two main branches, one is TaWC, flowing to 

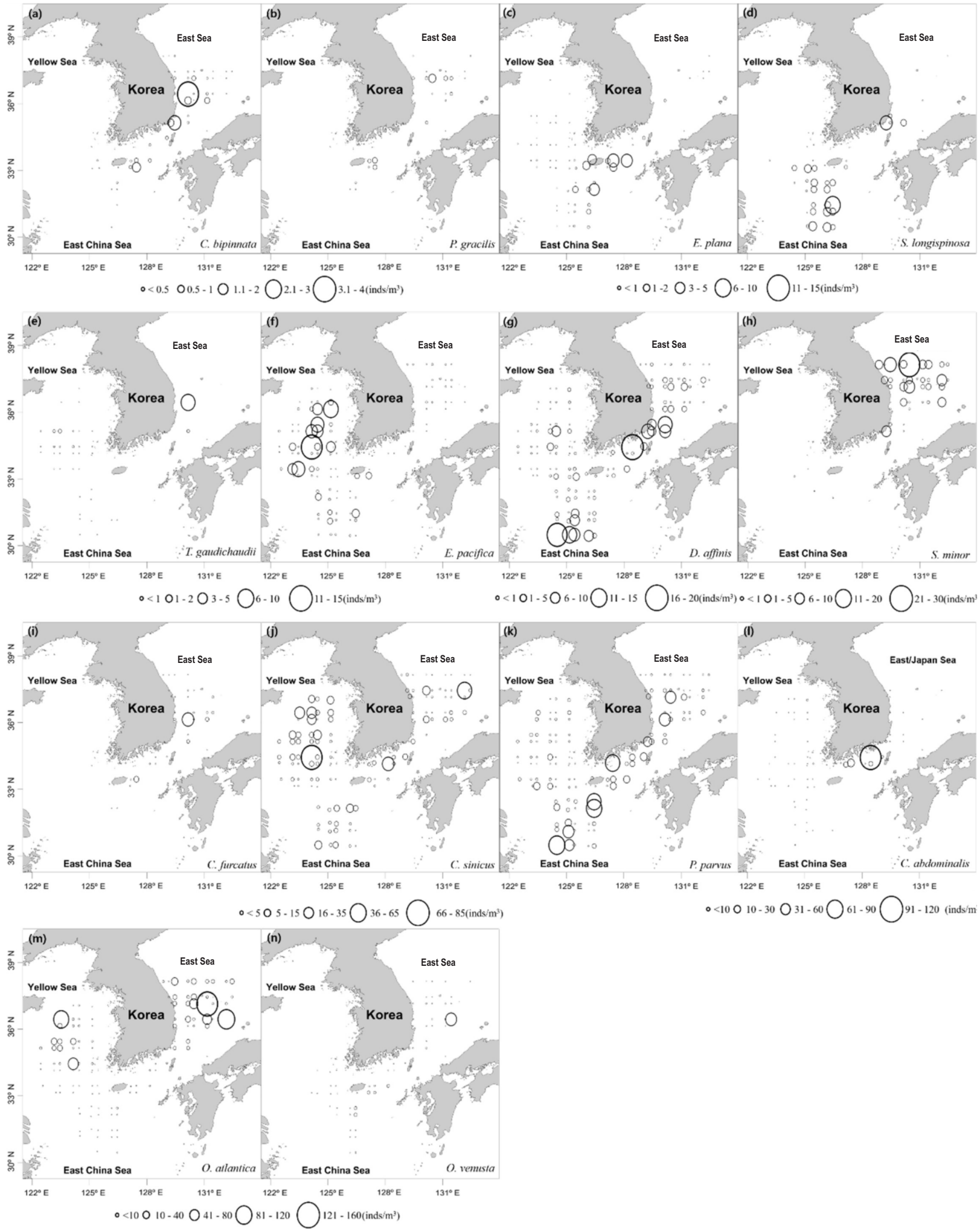

Fig. 9 : Distribution of indicator species: (a) Candacia bipinnata, (b) Pleuromamma gracilis, (c) Euchaeta plana, (d) Scolecithricella longispinosa, (e) Themisto gaudichaudii, (f) Euphausia pacifica, (g) Ditrichocorycaeus affinis, (h) Scolecithricella minor, (i) Corycaeus affinis, (j) Calanus sinicus, (k) Paracalanus parvus s.I., (I) Centropages abdominalis, (m) Oithona atlantica, (n) Oncaea venusta. 
Table 5 : Results of Spearman rank correlation coefficient between indicator species and temperature and salinity. '-' means p-value, >0.05

\begin{tabular}{|c|c|c|c|c|c|}
\hline \multirow[t]{2}{*}{ Current } & \multirow[t]{2}{*}{ Species } & \multicolumn{2}{|c|}{ Temperature } & \multicolumn{2}{|c|}{ Salinity } \\
\hline & & $r$ & $p$ & $r$ & $p$ \\
\hline NKCC & Scolecithricella minor & 0.227 & $<0.01$ & 0.084 & - \\
\hline \multirow[t]{6}{*}{ EKWC } & Candacia bipinnata & 0.529 & $<0.001$ & 0.725 & $<0.001$ \\
\hline & Calanus sinicus & -0.336 & $<0.001$ & -0.407 & $<0.001$ \\
\hline & Paracalanus parvuss.I. & 0.220 & $<0.05$ & 0.142 & - \\
\hline & Ditrichocory caeusaffinis & 0.411 & $<0.001$ & 0.313 & $<0.001$ \\
\hline & Clausocalanus furcatus & 0.328 & $<0.001$ & 0.541 & $<0.001$ \\
\hline & Pleuromamma gracilis & 0.290 & $<0.001$ & 0.423 & $<0.001$ \\
\hline \multirow[t]{4}{*}{ JWC } & Oncaea venusta & 0.713 & - & 0.789 & $<0.001$ \\
\hline & Euchaeta plana & 0.472 & $<0.001$ & 0.174 & $<0.001$ \\
\hline & Scolecithricella longispinosa & 0.584 & $<0.001$ & 0.321 & $<0.05$ \\
\hline & Oithona atlantica & -0.253 & $<0.01$ & 0.086 & - \\
\hline \multirow[t]{2}{*}{ YSWC } & Oithona atlantica & -0.253 & $<0.01$ & 0.086 & - \\
\hline & Themisto gaudichaudi & -0.264 & $<0.01$ & -0.456 & $<0.001$ \\
\hline \multirow[t]{2}{*}{ Y1 } & Centropages abdominalis & -0.122 & - & -0.176 & $<0.05$ \\
\hline & Euphausia pacifica & -0.318 & $<0.001$ & -0.505 & $<0.001$ \\
\hline
\end{tabular}

Table 6: Indicator species index in winter 2016. (Ind-Val, Indicator value)

\begin{tabular}{|c|c|c|c|c|c|}
\hline \multicolumn{6}{|c|}{ JWC } \\
\hline $\begin{array}{l}\text { Species } \\
\text { Oncaea venusta } \\
\text { Euchaeta plana } \\
\text { Scolecithricella longispinosa } \\
\text { Oithona atlantica }\end{array}$ & & $\begin{array}{l}\text { Ind-Val } \\
78.6 \\
76.4 \\
73.7 \\
66.8\end{array}$ & & & \\
\hline Oithona atlantica & \multicolumn{2}{|l|}{ NKCC } & \multicolumn{3}{|c|}{ EKWC } \\
\hline Species & Ind-Val & $p$-value & Species & Ind-Val & $p$-value \\
\hline \multirow[t]{2}{*}{ Pseudocalanus newmani } & 66.6 & - & $\begin{array}{l}\text { Calanus sinicus } \\
\text { Oncaea venusta } \\
\text { Paracalanus parvus s.I. } \\
\text { Ditrichocorycaeus affinis } \\
\text { Clausocalanus furcatus } \\
\text { Pleuromamma gracilis } \\
\text { Pseudocalanus minutus }\end{array}$ & $\begin{array}{l}76.5 \\
73.8 \\
73.7 \\
68.5 \\
63.9 \\
62 \\
60.3\end{array}$ & $\begin{array}{l}<0.05 \\
- \\
<0.05 \\
<0.05 \\
<0.05 \\
<0.01 \\
-\end{array}$ \\
\hline & YSWC & & ) & Y1 & \\
\hline Species & Ind-Val & $p$-value & Species & Ind-Val & $p$-value \\
\hline $\begin{array}{l}\text { Oithona atlantica } \\
\text { Ditrichocory caeusaffinis } \\
\text { Themisto gaudichaudi } \\
\text { Sagitta nagae }\end{array}$ & $\begin{array}{l}84.3 \\
69.8 \\
65.8 \\
63.8 \\
\end{array}$ & $\begin{array}{l}<0.01 \\
- \\
<0.05 \\
-\end{array}$ & $\begin{array}{l}\text { Centropages abdominalis } \\
\text { Euphausia pacifica }\end{array}$ & $\begin{array}{l}86.6 \\
77.8\end{array}$ & $\begin{array}{l}<0.001 \\
<0.001\end{array}$ \\
\hline
\end{tabular}

the northern ECS and another one is TsWC, flowing to the East/Japan Sea (Guan et al., 1982). Throughout the path, characteristics of TaWC and TsWC changed, and it affected JWC and EKWC, respectively. Although the East/Japan Sea was associated with northern ECS through the Korea Strait, community structures of zooplankton between the two seas were different in the present study.
Correlation zooplankton with temperature and salinity: $P$. newmani and M. pacifica, which were dominant in NKCC, were positively correlated with salinity during the study. 0 . atlantica was negatively correlated with temperature. In EKWC, P. minutes and M. pacifica were positively correlated with salinity. In JWC, C. sinicus had a negative correlation with temperature and salinity. In YSWC, O. atlantica was negatively correlated with temperature, 
while P. parvus s.l. was positively correlated (Table 5).

S. minor, indicator species of NKCC, was positively correlated with sea surface temperature. In EKWC, C. bipinnata had a strong positive correlation with sea surface temperature and salinity. $D$. affinis, $C$. furcatus and $P$. gracilis were positively correlated with sea surface temperature and salinity. P. parvus s.I. was positively correlated with sea surface salinity. C. sinicus was negatively correlated with temperature. In JWC, E. plana and $S$. longispinosa were positively correlated with sea surface temperature and salinity, while 0 . venusta was positively correlated with only sea surface salinity. 0 . atlantica, which was dominant species in both JWC and YSWC, was negatively correlated with sea surface temperature. In $Y 1, C$. abdominalis was negatively correlated with sea surface salinity, and another indicator species, E. pacifica, had a negative correlationship with temperature and salinity (Table 6).

Indicator species : Following the Indicator species analysis, $S$. minor was considered as an indicator species of NKCC and was dominated in northern East Sea. In EKWC, C. sinicus, P. parvus s.l. and $D$. affinis were broadly distributed in Korea, while $C$. furcatus, $C$. bipinnata and $P$. gracilis were distributed and dominated in southern East Sea. In JWC, O. atlantica dominated in Korean waters, while O. venusta was found in the East Sea and northern ECS. E. plana was distributed in the Yellow Sea and northern ECS, and highest in the vicinity of Jeju Island. The densities of $S$. longispinosa were highest in the eastern part of northern ECS and the Korea Strait. Themisto gaudichaudii which was an indicator species of the YSWC was broadly distributed in Korean water. In Y1, C. abdominalis and E. pacifica were broadly distributed in Korea and highest in the Yellow Sea. E. pacifica was most abundant in the Yellow Sea (Table 6, Fig. 9).

In this study, Korean water was divided into six water bodies to find the indicator species. Except for mixed water, five water bodies had indicator species. In the East Sea, S. minor which is an indicator species of sub-arctic water (Hooff et al., 2006) was an indicator species of NKCC and found in the East Sea and the southern sea of Korea (Jeong et al.,2014; Chiba et al.,2003). S. minorwas most abundant in the northern East/Japan Sea in the present study. S. minor can be an indicator species of NKCC. KWC features high water temperature and salinity, and formed the EKWC throughout the Tsushima Island (Rebstock et al., 2003). C. bipinnata, C. furcatus and $P$. gracilis were indicator species of KWC in the southern part of Japanese water (Noda et al.,1998). In the present study, these three species were positively correlated with sea water temperature and salinity, and could be indicator species of EKWC which was branch of the KWC. C. sinicus, P. parvus s.l. and D. affinis were broadly distributed in Korea, thus these species cannot be considered an indicator species.

In the East China Sea, Hsieh et al., (2004) reported O. venusta and $S$. longispinosa as indicator species of TaWC.
Distribution of S. Iongispinosa coincided with the path of JWC flowed from northern ECS to Korea Strait turning clockwise around Jeju Island. In addition, S. Iongispinosa was usually found off Yangtze river when salinity was high (Cheng et al., 2014). Following the studies, S. longispinosa can be considered to be a strong indicator species of JWC. Another indicator species, $E$. plana, was broadly distributed in the Korean water, but abundant only in the areas affected by JWC. E. plana is a warm water specie and was found to be abundant in the western part of Jeju Island (Park et al.,1992). O. atlantica was broadly distributed in Korea and cold water species (Chiba et al., 2003), thus it can not consider to be an indicator species of JWC which is characterized by high temperature and salinity.

The Yellow Sea has two currents, and T. gaudichaudii was the indicator species of YSWC. T. gaudichaudii was one of the most abundant amphipod specie of southern hemisphere (Mackey et al., 2012), particularly in Antarctic and sub-antarctic (Piatkowski, 1985). In this study, T. gaudichaudii showed a negative relationship with temperature and salinity. In northern Yellow Sea, C. abdominalis was relatively higher in the cold waters and occurred in the northern part of Yellow Sea (Kang et al., 2008). This species was found in cold-neritic seas (Jang et al., 2012). Y1 features lowest sea surface temperature and salinity, the environment where $C$. abdominalis occurs. Another indicator species, E. pacifica was broadly distributed in Korea, and abundant in the southern Yellow Sea. However, krill swarms were patchily distributed (Powell and Okubo, 1994). Thus, it is hard to survey quantitative analysis of the krill and to select an indicator species.

Three sides of Korean peninsula are surrounded by seas with different physical and biological characteristics driven by water currents: NKCC, EKWC, JWC, YSWC, Y1, and mixed water. The water bodies of the Yellow Sea and northern ECS were highly similar, but East Sea Sea was distinguished from others. Indicator species varied with varying water bodies, and the similarity of zooplankton community structures varied with the interaction of water masses.

\section{Acknowledgment}

This work was supported by a Research Grant of Pukyong National University(2017 year).

\section{References}

Beardsley, R.C., R. Limeburner, H. Yu and G.A. Cannon: Discharge of the Changjiang (Yangtze River) into the East China Sea. Cont. ShelfRes., 4, 57-76 (1985).

Brodsky, K.A.: Calanoida of the Far Eastern Seas and Polar Basin of the USSR. Keys to the Fauna of the USSR. The Zoological Institute of the Academy of Sciences of the USSR, 35, 1-440 (1950).

Chen, C.T. A.: Chemical and physical fronts in the Bohai, Yellow and East China Seas. J. Mar. Syst., 78, 394-410 (2009). 
Chen, H.Y. and Y.L.L. Chen: Quantity and quality of summer surface net zooplankton in the Kuroshio current-induced upwelling northeast of Taiwan. TAO, 3, 321-334 (1992).

Chen, H. and G. Liu: Zooplankton community structure in the Yellow Sea and East China Sea in autumn. Brazilian J. Oceanogr., 63, 455$468(2015)$.

Chen, Q.C., S.Z. Zhang and C.S. Zhu: On planktonic copepods of the Yellow Sea and the East China Sea. II. Cyclopoida and Harpacticoida. Stud. Mar. Sin., 9, 27-76 (1974).

Cheng, F., M. Wang, C. Li and S. Sun: Zooplankton community analysis in the Changjiang River estuary by single-gene-targeted metagenomics. CJOL, 32, 858-870 (2014).

Chiba, S. and T. Saino: Variation in mesozooplankton community structure in the Japan/East Sea (1991-1999) with possible influence of the ENSO scale climatic variability Prog. Oceanogr., 57,317-339 (2003).

Cho, Y.K. and K. Kim: Two modes of the salinity-minimum layer water in the Ulleung Basin. La mer, 32, 271-278 (1994).

Choi, M.Y., D.S. Moon, D.H. Jung and H.J. Kim: Seasonal distribution of water masses and spatio-temporal characteristics of nutrients in the coastal areas of Gangwon Province of the Korean East Sea in 2009. J. Korean Soc. Mar. Environ. Energ., 15, 76-88 (2012).

Clarke, K.R. and R.M. Warwick: A further biodiversity index applicable to species lists: Variation in taxonomic distinctness. Mar. Ecol. Prog. Ser., 216, 265-278 (2001).

Dufrene, M. and P. Legendre: Species assemblages and indicator species: The need for a flexible asymmetrical approach. Ecol. Monogr., 67, 345-366 (1997).

Dur, G., J.S. Hwang, S. Souissi, L.C. Tseng, C.H. Wu, S.H. Hsiao and Q.C. Chen: An overview of the influence of hydrodynamics on the spatial and temporal patterns of calanoid copepod communities around Taiwan. J. Plankton Res., 29, 97-116 (2007).

Fang, G., B. Zhao and Y. Zhu: Water volume transport through the Taiwan Strait and the continental shelf of the East China Sea measured with current meters. Elsevier Oceanogr. Ser., 54, 345-358 (1991).

Guan, B. and H. Mao:A note on circulation of the East China Sea. Chin. J. Oceanol. Limnol., 1, 5-16 (1982).

Hooff, R.C. and W.T. Peterson: Copepod biodiversity as an indicator of changes in ocean and climate conditions of the northern California current ecosystem. Limnol. Oceanogr., 51, 2607-2620 (2006).

Hsieh, C.H.H., T.S. Chiu and C.T. Shih: Copepod diversity and composition as indicators of intrusion of the Kuroshio Branch Current into the Northern Taiwan Strait in Spring 2000. Zool. Stud., 43,393-403 (2004).

Hsueh, Y.: Recent current observations in the eastern Yellow Sea. J. Geophys. Res. Oceans, 93, 6875-6884 (1988).

Hwang, J.H., S.P. Van, B.J. Choi, Y.S. Chang and Y.H. Kim: The physical processes in the Yellow Sea. Ocean Coast Manag., 102, 449-457 (2014).

Hwang, J.S. and C.K. Wong: The China coastal current as a driving force for transporting Calanus sinicus (Copepoda: Calanoida) from its population centers to waters off Taiwan and Hong Kong during the winter northeast monsoon period. J. Plankton Res., 27, 205-210 (2005)

Hwang, J.S., S. Souissi, L.C. Tseng, L. Seuront, F.G. Schmitt, L.S. Fang and T.P. Wei: A 5-year study of the influence of the northeast and southwest monsoons on copepod assemblages in the boundary coastal waters between the East China Sea and the Taiwan Strait. J. Plankton Res., 28, 943-958 (2006).
Ichikawa, H. and R.C. Beardsley: The current system in the Yellow and East China Seas. J. Oceanogr., 58, 77-92 (2002).

Isoda, Y., S. Saitoh and M. Mihara: Seasonal variations of SST patterns in the Japan Sea. Umi to Sora, 68, 113-124 (1992).

Jang, M.C., S.H. Baek, P.G. Jang, W.J. Lee and K.S. Shin: Patterns of zooplankton distribution as related to water masses in the Korea strait during winter and summer. Ocean Polar Res., 34, 37-51 (2012).

Jeong, H.G., H.L. Suh, W. Lee and H.Y. Soh: Seasonal variation of the neustonic zooplankton community in southern waters of Korea. Ocean Sci. J., 49, 167-181 (2014).

Kang, J.H., W.S. Kim, H.J. Jeong, K. Shin and M. Chang: Why did the copepod Calanus sinicus increase during the 1990s in the Yellow Sea? Mar. Environ, Res., 63, 82-90 (2007)

Kang, J.H. and W.S. Kim: Spring dominant copepods and their distribution pattern in the Yellow Sea. Ocean Sci. J., 43, 67-79 (2008).

Kim, K., K.R. Kim, J.Y. Chung, H.S. Yoo and S.G. Park: Characteristics of physical properties in the Ulleung Basin. J. Oceanol. Soc. Korea, 26, 83-100 (1991).

Kim, S. W. and Y. Isoda: Interannual variations of the surface mixed layer in the Tsushima current region. Umi to Sora, 74, 11-22 (1998).

Koh, C.H. and J.S. Khim: The Korean tidal flat of the Yellow Sea: Physical setting, ecosystem and management. Ocean Coast. Manag., 102, 398-414 (2014).

Kondo, M.: Oceanographic investigations of fishing grounds in the East China Sea and the Yellow Sea, 1: Characteristics of mean temperature and salinity distributions measured at $50 \mathrm{~m}$ and near the bottom. Bull. Seikai Reg. Fish. Res. Lab., 62, 19-66 (1985).

Lan, Y.C., C.T. Shih, M.A. Lee and H.Z. Shieh: Spring distribution of copepods in relation to water masses in the northern Taiwan Strait. Zool. Stud., 43, 332-343 (2004).

Lee, C.K.: The drift bottle experiment in the east of the Yellow Sea (the west coast of Korea) during the year of 1962-1966. Bull. Fish. Res. Develop. Agency, 3, 29-41 (1968).

Lee, D.I. and J.K. Kim: Numerical simulation of residual currents and tow salinity dispersions by Changjiang discharge in the Yellow Sea and the East China Sea. J. Korean Soc. Mar. Environ. Energ., 10, 67$85(2007)$.

Lee, S.W.: The Maritime of Coast of Korea. Jib-mun-dang (1992).

Lie, H.J.: A note on water masses and general circulation in the Yellow Sea (Hwanghae). J. Oceanol. Soc. Korea, 19, 187-194 (1984).

Lie, H.J and C.H. Cho: On the origin of the Tsushima Warm Current. J. Geophys. Res.: Oceans, 99, 25,081-25,091 (1994).

Lie, H.J.: Ocean circulation in the western and middle part of the East China Sea (second year). KORDI Rep. BSPE 98708-00-1141-1 (1999).

Lie, H.J.: and C.H. Cho: Recent advances in understanding the circulation and hydrography of the East China Sea. Fish. Oceanogr., 11, 318-328 (2002).

Lie, H.J., C.H. Cho, J.H. Lee, S. Lee and Y. Tang: Seasonal variation of the Cheju warm current in the northern East China Sea. J. Oceanogr., 56,197-211 (2000).

Lie, H.J., C.H. Cho, J.H. Lee, S. Lee, Y. Tang and E. Zou: Does the Yellow Sea Warm Current really exist as a persistent mean flow? J. Geophys. Res.: Oceans, 106, 199-210 (2001).

Lim, D.H., W. D., Yoon, J. W. Yang and Y. Lee: The seasonal fluctuation of zooplankton in the Yellow Sea. J. Korean Soc. Mar. Environ. Saf., 183-188 (2009). 
Mackey, A.P., A. Atkinson, S.L. Hill, P. Ward, N.J. Cunningham, N.M. Johnston and E.J. Murphy: Antarctic macrozooplankton of the southwest Atlantic sector and Bellingshausen Sea: Baseline historical distributions (Discovery Investigations, 1928-1935) related to temperature and food, with projections for subsequent ocean warming. Deep Sea Res., Part II, 59,130-146 (2012).

Naimie, C.E., C.A. Blain and D.R. Lynch: Seasonal mean circulation in the Yellow Sea a model generated climatology. Cont. Shelf Res., 21,667-695 (2001).

Nitani, H.: Beginning of the Kuroshio, in Kuroshio- its physical aspects, University of Tokyo Press, Tokyo (1972).

Noda, M., I. Ikeda, S. Ueno, H. Hashimoto and K. Gushima: Enrichment of coastal zooplankton communities by drifting zooplankton patches from the Kuroshio front. Mar. Ecol. Prog. Ser., 170, 55-65 (1998).

Park, C. and J. Seo: Characteristics of zooplankton distribution and degree of its coupling with distribution of water masses in the northern East China Sea in summer and winter. The Yellow Sea, 6, 1-11 (2000).

Park, C., C.R..Lee and J.C. Kim: Zooplankton community in the front zone of the East Sea (the Sea of Japan), Korea: 2. Relationship between abundance distribution and Seawater temperature. Korean J. Fish. Aquat. Sci., 31, 749-759 (1998).

Park, J.S., S.S. Lee, Y.S. Kang, B.D. Lee and S.H. Huh: Distribution of indicator species of copepods and chaetognaths in the southeastern area of the Yellow Sea and their relationship to the characteristics of water masses. Korean J. Fish. Aquat. Sci., 25, 251-264 (1992).

Park, K.A., D.S. Ullman, K. Kim, J.Y. Chung and K.R. Kim: Spatial and temporal variability of satellite-observed subpolar front in the East/Japan Sea. Deep Sea Res., Part I, 54, 453-470 (2007).

Piatkowski, U.: Distribution, abundance and diurnal migration of macrozooplankton in Antarctic surface waters. MeeresforschungReports on Marine Res., 30, 264-279 (1985).

Powell, T.M. and A. Okubo: Turbulence, diffusion and patchiness in the sea. Philos. Trans. R. Soc., B, 343, 11-18(1994).

Rebstock, G.A. and Y.S. Kang: A comparison of three marine ecosystems surrounding the Korean peninsula: Responses to climate change. Prog. Oceanogr., 59, 357-379 (2003).

Riedlinger, S.K. and G. Jacobs: Study of the dynamics of wind-driven transports into the Yellow Sea during winter. J. Geophys. Res. Oceans, 105, 695-708 (2000).

Riedlinger, S. and R. Preller: Validation test report for the Yellow Sea shallow water analysis and forecast system. Draft NRL Report, Stennis Space Center, MI. (1995).

Shanks, A.: An Identification Guide to the Larval Marine Invertebrates of the Pacific Northwest. Oregon State Univ. Press. (2001).

Shannon, C.E. and W. Weaver: The measurement theory of communication. University of Illinois Press, Urbana (1963).

Teague, W.J., G.A. Jacobs, D.S. Ko, T.Y. Tang, K.I. Chang and M.S. Suk: Connectivity of the Taiwan, Cheju, and Korea Straits. Cont. Shelf Res., 23, 63-77 (2003).

Tseng, L.C., S. Souissi, H.U. Dahms, Q.C. Chen and J.S. Hwang: Copepod communities related to water masses in the southwest East China Sea. Helgoland Mar. Res., 62,153 (2008).

Uda, M.: The results of simultaneous oceanographical investigations in the Japan Sea and its adjacent waters in May and June, 1932. J. Imper. Fish. Exper. Stat., 5, 57-190 (1934).

Yasui, M.: Oceanographic studies of the Japan Sea (1)-Water characteristics. Oceanogr. Magaz., 19,177-192 (1967).

Yoo K.I.: Zooplankton studies of the Yellow Sea in Korea. Yellow Sea Res., 4, 31-37 (1991).

Yoon, J.H.: Numerical experiment on the circulation in the Japan Sea. J. Oceanogr. Soc. Japan, 38, 81-94 (1982). 